\title{
Conceptualization of an Abstract Language to Support Value Co-Creation
}

\author{
Christophe Feltus, Erik HA Proper \\ Luxembourg Institute of Science and Technology, \\ 5, avenue des Hauts-Fourneaux, \\ L-4362 Esch-sur-Alzette, Luxembourg \\ \{firstname.name\}@1ist.lu
}

\begin{abstract}
Companies willing to survive the numeric economy are forced to collaborate with each other in order to maximize their co-creation of value. This co-creation exists for many reasons: to sell and acquire information, goods and services, to optimize the quality of procedures, to improve security and privacy, etc. In this paper, we analyze and model value cocreation through three dimensions: the value's nature, the method of value creation, and the business object impacted by the value. By combining these dimensions, we afterwards suggest different types of co-creation schemas, and we propose an abstract language to communicate them. The latter is finally validated by applying the "The Physics of Notations" guidelines.
\end{abstract}

\section{INTRODUCTION}

Companies willing to survive the web economy must collaborate with each other to maximize their co-creation of value. For long, information system (IS) design and engineering has been motivated and inspired by the need to optimize value design and value delivery (e.g., e3value [1], ArchiMate $^{\circledR}$ [2], Demo [3], the value delivery metamodel from the OMG [4]). In this context, two or more companies engaged in value co-creation (VCC) have to define, create and manage the value they co-create. Therefore, they must use appropriate tools to support and manage the co-creation, amongst them, models and dedicated languages that support communication and information sharing between involved parties. Unfortunately, designing such a unique language, with a concrete syntax, to express all the VCC dimensions remains challenging for three reasons:

The $1^{\text {st }}$ reason is that value may be of different natures (e.g. security, quality, privacy,...) and each type of nature uses its own type of language (e.g., ISSRM [5] relates to security, Quality Model relates to quality [6], or Privacy metamodel relates to privacy [7], [8]). Moreover, this nature is only significant in the context in which the relevant value exists. For instance, the value of privacy is more important in the healthcare sector than in bookstores. The value of a pecuniary type has more relevance for a profit organization than for a non-profit one. Or the value of a well-being type is more important in a SME than in an international company.

The $2^{\text {nd }}$ reason is that value is often created using different methods, in a function of the sensibilities and preferences of the companies, and each method is defined using its own syntax (e.g., method by design [9], method chunk [10], or model-driven approach [11]).

The research is supported by the National Research Fund, Luxembourg (http://www.fnr.lu) and financed by the ValCoLa (VCC Language) project.
The $3^{\text {rd }}$ reason is that objects concerned by the value are not necessarily the same for each company and, as a result, these objects may have different functions for the enterprise. In parallel, these enterprises are generally modelled using different frameworks depending on the sectors they belong to. That means that each company's context may be described with a dedicated language (e.g., ArchiMate ${ }^{\circledR}$ [2], Aris [12], or CIMOSA [13]). Additionally, value is sometimes co-created at different layers of the company. For instance, in some cases, the value is created by the IT service, and in other cases, by business developers. In this case, two different languages are necessary: one to be understood by IT specialists, the other to be understood by business men.

In this paper, we focus on VCC at the IS level and provides a new perspective on the traditional one-dimension VCC. Indeed, the co-creation of value that considers that a firm is invited by a customer to make a value proposition offer only in exchange of money is too short-sighted. Our idea is that (1) VCC is built upon multi-dimensions because it supports the co-creation of value for all the parties (business entities) involved, (2) it is co-created using different methods in accordance to the parties engaged and these methods have to be integrated with each other, and (3) the object of value is potentially of a different nature in a function of the sector implied.

In the next sections, we review VCC state of the art through different disciplines. In Section III, the three value dimensions are presented and based on the latter, we introduce VCC schemas in Section IV. In Section V, we present the VCC abstract language that we validate in Section IV. Finally, we conclude and present future works in Section VII.

\section{STATE OF THE ART}

VCC discipline originates from the marketing theory. It aims to define and to explain the mechanism for the cogeneration of value during business exchanges amongst two or more companies [15]-[17]. Vargo et al. [16], [17] formalized it using a framework for defining VCC in the perspective of the service dominant logic (S-DL). According to the authors, service is the basis of all exchanges and focuses on the process of value creation rather than on the creation of tangible outputs. As a result, a service system is a network of agents and interactions that integrates resources for VCC 
[16]. On that basis, Vargo et al. further elaborate on the idea that value is derived and determined in use rather than in exchange. That means that value is proposed by a service provider and is determined by a service beneficiary. Hence, the firm is in charge of the value-creation process and the customer is invited to join in as a co-creator [16]. For Grönroos et al. [14], this interaction is defined through situations in which the customer and the provider are involved in each other's practices. Consequently, the context (social, physical, temporal and/or spatial) determines the value-in-use experience of the user in terms of his individual or social environment. Another conceptual framework for VCC has been proposed by Payne et al. [8]. This framework is composed of three processes: customer value-creating, supplier value-creating, and value encounter for which goals are defined in a customer learning perspective and may be of a type that can be cognitive, emotive, and behavioral. The idea behind being that the more the customer understands about the business opportunities, the greater the value. Hastings et al. [19] also define a set of six concepts to design the practicedriven service framework for value creation, to know: customers co-create value with providers, value is created in service systems, modular business architecture, scalable GloMo-So (global, mobile, social) platforms, continuous improvement via learning, and multi-sided metrics. At the analytical level, Storkacka et al. [20] have complementarily proposed to analyze the actors' engagement as a microfoundation (explanation on a low analytical level) for $\mathrm{VCC}$ and Frow et al. [21] propose a framework to assist firms in identifying new opportunities for value co-creation. Therefore, the authors provide a strategically important new approach for managers to identify, organize and communicate innovative opportunities.

Recently, Chew [22] has argued that, in the digital world, service innovation is focused on customer value creation and he proposes an integrated Service Innovation Method (iSIM) that allows analyzing the interrelationships between the design process elements, including the service system. The latter being defined as an IT/operations-led cross-disciplinary endeavor. At the information system domains level, Gordijn et al. [23] explain that business modeling is not about process but about value exchange between different actors. Accordingly, in [1], Gordijn et al. propose e3value to design models that sustain the communication between business and IT groups, particularly in the frame of the development of e-business systems. In [24], Weigand extends e3value language for considering co-creation. Therefore, he defines the so called value encounters which consist in spaces where groups of actors interact to derive value from the groups' resources. In the same vein, Razo-Zapata et al. propose visual constructs to describe the VCC process [25]. These constructs are built on requirements from the service dominant logic and software engineering communities. They aim is to express three cocreation types (co-ordination, co-operation and collaboration) following the three elements of the customer relationship experience: cognition, emotion and behavior [18]. According to [26], the co-creation may happen through different processes (B2C, B2B, C2B or C2C) and may refer to different types of value (for the company or the customer).

Two of the existing states of the art in the field of VCC are particularly interesting. The first one reviews the existing literature through both following perspectives: co-production and value-in-use [27], and the second one through two dimensions: theoretical dimension of the co-creation, and collaboration and co-creation between firms and customers [28]. Despite the undeniable need for designing an effective language to support the VCC management [1], [24], [25], the review of the state of the art demonstrates that, up to date, no approach fully considers all the dimensions necessary to cover the VCC domain.

\section{VALUE DEFINITION AND PERIMETER}

In this section, value is defined according to the following three dimensions (Fig. 1): the nature of the value, the method of VCC, the object concerned by VCC. In the next subsections, each dimension is conceptualized, modeled and illustrated with real cases.

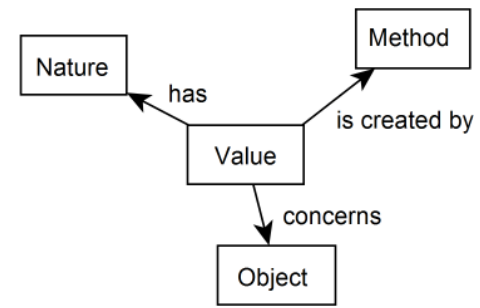

Fig. 1. Three value dimensions

At a methodological level, the research that we tackle concerns the improvement of value management in the field of interconnected societies. Accordingly, we have conceptualized and defined the abstract language to support the value cocreation on the basis of the three value dimensions mentioned here above. Through this research, we aim to strengthen the organizational capability to improve the design of the information system which sustains VCC. Accordingly, Hevner et al. [29] explain that the Design Science Research (DSR) paradigm seeks to extend the boundaries of human and organization capability by creating new and innovative artefacts. Practically, provided that we aim to design a new artefact (abstract language for VCC) to support the design of the information system, we acknowledge that this research may plainly be considered in the scope of DSR [30]. As advocated by the DSR theory [29], [30], the method that we use to design these value dimensions is an iterative approach consisting first of analyzing different instances of the domain under scope, second of extracting the relevant concepts from the instances, and third of designing elementary domain models. E.g., to model the nature of the value, we have analyzed some instances of this nature like security, privacy, quality, we have extracted the more relevant concepts of these domains in Table II, and we have designed the nature of the 
value model (Fig. 2). For the sake of pragmatism, only the last version of the iterations are presented in the next sections.

\section{A. Nature of the value}

Value is an abstract concept that expresses a measureable information of a determined nature and which is associated to a well-defined object. According to Zeithaml, value implies some form of assessment of benefits against sacrifices [15]. Most researches that focus on depicting the semantic of value agree on the abstract character of the latter, mostly generated by the different types of existing value nature [26]. Whatever, two main categories of value nature emerge depending on the context: value at provider side vs. value at customer side. When value is perceived at the provider side, economists largely argue that the latter is created (manufactured) by the firm and distributed in the market, usually through exchange of goods and money [31]. This nature of value has for a long time traditionally been represented by the possession of wealth and money. However, it is also worth to note that considering the provider in the context of the digital society expands this narrow mind meaning to the consideration of other value elements, like the information collected on the customers which, afterwards, fills the bill of economic increase [32]. On the customer side, value generated by a transaction never refers to money but consists in other wealth, which contributes in sustaining and supporting the customer's owns business.

Let us take the example of a SME that outsources the privacy management of its assets to dedicated enterprises, in order to remain being focused on its core business. In this case, the privacy nature of the value is traditionally expressed with well-defined characteristics (e.g., pseudonymity, anonymity, consent, etc. (see Table I) that are specifics for privacy). Moreover, two types of value are created by this outsourcing: a direct value (privacy of the assets) and an indirect value (more time for core activities). Over and above that, this transaction happening with a customer being a citizen also contributes to the latter's improvement of his wellbeing as observed in [33] that asserts that value for customer means that after they have been assisted by a self-service process or a full-service process, they are or feel better off than before.

As summarized in Table I, our analysis to understand and to define the nature of the value has been performed by tackling a set of frameworks in different areas like security, quality, compliancy, privacy, responsibility, and so forth. For instance, we have analyzed the Information Systems Security Risks Management (ISSRM [5]) framework that addresses the IS security. ISSRM characterizes security through integrity, confidentiality, non-repudiation and accountability, availability, and the latter concerns business asset of the company. Moreover, according to [34], we acknowledge that the above mentioned characteristics also constitute complementary types of value.

Based on our review, we have observed that value is an abstract concept defined by a well precise nature with well determined characteristics, that it is measureable and that it concerns a well-defined object.

TABLE I. NATURE OF THE VALUE

\begin{tabular}{|c|c|c|c|}
\hline \multirow{2}{*}{$\begin{array}{c}\text { Value } \\
\text { reference } \\
\text { framework }\end{array}$} & \multicolumn{3}{|c|}{ Nature of the Value examples } \\
\hline & $\begin{array}{c}\text { Nature of the } \\
\text { value }\end{array}$ & $\begin{array}{c}\text { Characteristics of the } \\
\text { nature of the value }\end{array}$ & $\begin{array}{c}\text { Concerned } \\
\text { object }\end{array}$ \\
\hline ISSRM [5] & IS Security & $\begin{array}{c}\text { Confidentiality, } \\
\text { Integrity, Availability, } \\
\text { Non-repudiation, } \\
\text { Accountability }\end{array}$ & $\begin{array}{c}\text { Business } \\
\text { Asset }\end{array}$ \\
\hline ReMMo [35] & Responsibility & $\begin{array}{c}\text { Accountability (e.g., } \\
\text { RACI) }\end{array}$ & Actor \\
\hline $\begin{array}{l}\text { Web Quality } \\
\text { Model [6] }\end{array}$ & Quality & $\begin{array}{c}\text { Functionality, } \\
\text { Reliability, Usability, } \\
\text { Efficiency, Portability, } \\
\text { Maintainability }\end{array}$ & Web feature \\
\hline $\begin{array}{c}\text { EA } \\
\text { Compliance } \\
\text { Model [36] }\end{array}$ & Compliancy & $\begin{array}{l}\text { Correctness, } \\
\text { Justification, } \\
\text { Consistency, } \\
\text { Completeness }\end{array}$ & $\begin{array}{c}\text { Acts of } \\
\text { software } \\
\text { developers }\end{array}$ \\
\hline $\begin{array}{c}\text { Privacy } \\
\text { Metamodel } \\
{[7] \text { and [8] }}\end{array}$ & Privacy & $\begin{array}{l}\text { Notice, Choice and } \\
\text { Consent, Proximity } \\
\text { and Locality, } \\
\text { Anonymity and } \\
\text { Pseudonymity, } \\
\text { Security, and Access } \\
\text { and Resource [13] }\end{array}$ & $\begin{array}{c}\text { Sensitive } \\
\text { Information } \\
{[9]}\end{array}$ \\
\hline VDML [4] & $\begin{array}{c}\text { Generic } \\
\text { Value }\end{array}$ & $\begin{array}{l}\text { Factor of benefit, } \\
\text { Factor of interest }\end{array}$ & $\begin{array}{l}\text { Business } \\
\text { item [24] }\end{array}$ \\
\hline HCI [37] & Usability & $\begin{array}{c}\text { Learnability, } \\
\text { Flexibility, Robustness }\end{array}$ & $\begin{array}{c}\text { Design rules, } \\
\text { design } \\
\text { knowledge }\end{array}$ \\
\hline$\ldots$ & & & \\
\hline
\end{tabular}

The concepts composing the nature of the value model are:

- Nature of the value. The nature of the value expresses a domain of interest and a context that characterize an element of the information system. (e.g., security of the IS, the cost of a transaction, or the privacy of personal data)

- Characteristics of the Nature of the Value. This concept expresses the different elements that characterize the nature of the value, or the pillars that found this nature. (e.g., availability, confidentiality, portability, etc.)

- Object. The object concerned by the value is the IS element that will be better off after that value is delivered (e.g., an actor, a process, a data)

- Measure. The measure corresponds to a property on which calculations can be made for determining the amount of value generated.

Based on the above definitions, the nature of the value has been modeled in Fig. 2.

\section{B. Method of value creation}

A method of value creation is a formalized activity which contributes to the generation of value. Traditionally, value is acquired by exchanging goods or services and it emerges out of its use [2]. Methods for value creation are the body of techniques and series of steps necessary to create value. This corresponds, at the corporate level, to a bundle of approaches including processes, audits, controls, decisions, etc. 


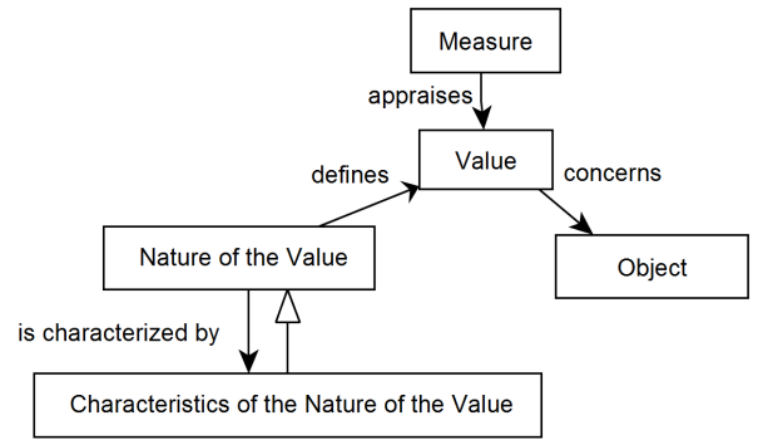

Fig. 2. Nature of the Value

Likewise, as for the nature of the value, in order to depict the elements relevant for the creation of value, we have reviewed a set of value creation methods amongst a plethora of them (Table II). The methods that we analyzed so far are the impact assessment [38], the method by design [9], the process based [39] and the risk based method [40], the model driven approaches [11] and the "method chunk" [10]. By looking more closely to all of them, we observe that these methods have each a dedicated goal, that they are composed of method elements and that the latter are organized in ordinate steps. For instance, by investigating the model driven approach, we notice that it has for goal to improve interoperability of enterprises information systems, that it is composed of models, and that three steps are required for model driven interoperability, to know: models design, models integration and models instantiation.

TABLE II. METHOD OF VALUE CREATION

\begin{tabular}{|c|c|c|c|c|}
\hline \multirow{2}{*}{$\begin{array}{l}\text { Method } \\
\text { refe- } \\
\text { rence }\end{array}$} & \multicolumn{4}{|c|}{ Method of Value creation examples } \\
\hline & Method & $\begin{array}{l}\text { Goal of the } \\
\text { method }\end{array}$ & $\begin{array}{l}\text { Method } \\
\text { elements }\end{array}$ & Steps of the method \\
\hline [11] & $\begin{array}{l}\text { Model- } \\
\text { driven }\end{array}$ & $\begin{array}{l}\text { Improve } \\
\text { interopera- } \\
\text { bility of } \\
\text { companies } \\
\text { information } \\
\text { systems }\end{array}$ & Model & $\begin{array}{l}\text { Models design, model } \\
\text { integration and model } \\
\text { instantiation }\end{array}$ \\
\hline [38] & $\begin{array}{c}\text { Impact } \\
\text { assessment }\end{array}$ & $\begin{array}{l}\text { Explore } \\
\text { social } \\
\text { consequen- } \\
\text { ces for } \\
\text { social } \\
\text { security } \\
\text { policies }\end{array}$ & $\begin{array}{l}\text { Scenario, } \\
\text { Strategy, } \\
\text { Impacts, } \\
\text { Imple- } \\
\text { mentation }\end{array}$ & $\begin{array}{c}\text { Scenario design, } \\
\text { Design of strategies, } \\
\text { Assessment of impacts, } \\
\text { Ranking of strategies, } \\
\text { Mitigation of negative } \\
\text { impacts, Reporting, } \\
\text { Stimulation of } \\
\text { implementation, } \\
\text { Auditing and ex-post } \\
\text { evaluation }\end{array}$ \\
\hline [10] & $\begin{array}{l}\text { Method } \\
\text { chunk }\end{array}$ & $\begin{array}{l}\text { Method } \\
\text { creation }\end{array}$ & $\begin{array}{l}\text { Chunk of } \\
\text { existing } \\
\text { methods }\end{array}$ & $\begin{array}{l}\text { Decomposition of } \\
\text { existing methods into } \\
\text { method chunks and } \\
\text { definition of new } \\
\text { method chunks from } \\
\text { scratch }\end{array}$ \\
\hline [40] & $\begin{array}{l}\text { Risk- } \\
\text { based }\end{array}$ & $\begin{array}{l}\text { Security } \\
\text { strategy } \\
\text { develop- } \\
\text { ment }\end{array}$ & $\begin{array}{l}\text { Risk, } \\
\text { Costs, } \\
\text { Benefits }\end{array}$ & $\begin{array}{l}\text { Analysis of the } \\
\text { methods elements and } \\
\text { identification of the } \\
\text { options that exist in } \\
\text { investment decisions }\end{array}$ \\
\hline
\end{tabular}

\begin{tabular}{|c|c|c|c|c|}
\hline [39] & $\begin{array}{c}\text { Risk } \\
\text { Panage- } \\
\text { based } \\
\text { ment for } \\
\text { global } \\
\text { supply } \\
\text { chain }\end{array}$ & $\begin{array}{c}\text { Process, } \\
\text { Step, } \\
\text { Depen- } \\
\text { dency }\end{array}$ & $\begin{array}{c}\text { Step-by-step execution } \\
\text { in a function of the } \\
\text { dependency amongst } \\
\text { them }\end{array}$ \\
\hline [9] & By design & $\begin{array}{c}\text { Prevent } \\
\text { privacy risk } \\
\text { from } \\
\text { occurring }\end{array}$ & Project & $\begin{array}{c}\text { Project-by-project } \\
\text { approach realization }\end{array}$ \\
\hline$\ldots$ & & & & \\
\hline
\end{tabular}

Amongst the other methods reviewed, it is interesting to highlight that one of them (method chunk) has for particular objective the creation of method themselves, using, as method element: chunk of existing methods, and as method steps: the decomposition of existing methods into method chunks and the definition of new method chunks from scratch [10]. As a summary and according to our analysis, the concepts which compose the method of value creation are:

- Method. The method is an abstract concept that gathers a set of method elements ordered in steps (e.g., process based approach...)

- Goal. The goal corresponds to the expected operation on value created by the method (e.g., create value, assess or evaluate value generated, optimize the value)

- Method element. The elements of the method correspond to unitary tasks that constitute the method. (e.g., analysis, collect of information, reporting...)

- Method step. The method steps consist in the organized and coherent articulations of the method elements (e.g., if then else, process elements ordination...)

Based on the above definitions, the value creation method has been modeled in Fig. 3.

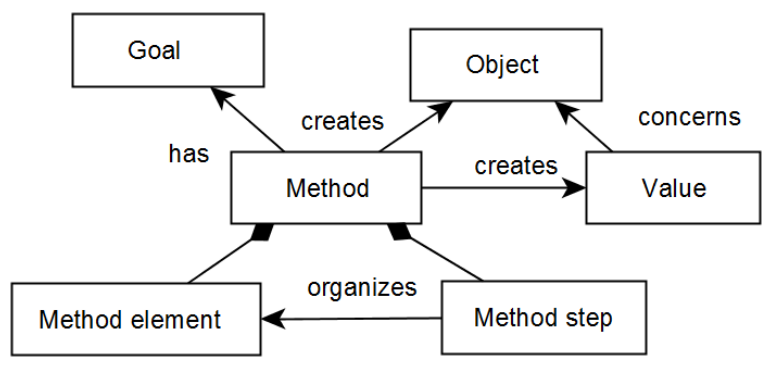

Fig. 3. Value creation method

\section{Object concerned by the value}

The object concerned by the value corresponds to the elements (mostly existing at the information system level, e.g., information, process, tool, actor) that have significance for a company to achieve its goal. This object exists in a determined environment represented at the information system level by the context, the latter having an influence on the type and the amount of value associated to this object. For instance, a customer browsing history is an object of a data type that has a particular pecuniary value for an airline travel agency which can estimate the value ascribed to a flight ticket for a customer. This value is calculated based on the number of times this flight ticket was viewed on the company website by 
the customer. At the opposite, this customer browsing history is not an object of value on a drugstore website with fixed prices. Complementarily, it is also worth to note that this context has no impact on the nature of the value. E.g., privacy in the healthcare sector is defined the same way as in the industry, meaning, with the same characteristics.

To collect and to deal with the concepts that are necessary to model the object of value, we assume that each sector of activities, should it be the manufacturing, the finance, or the healthcare sector for instance, is associated with a specific information system. The latter models the objects composing them and the relationships between these objects, using a dedicated language. In order to focus on the right object of value when defining a business model or when analyzing the co-creation of value, it is important to have an understanding of, and an alignment between, the objects of value of all stakeholders involved. The sector specific information systems and enterprise architecture (EA) models and languages are therefore good approaches because they semantically define generic objects and sometimes concrete languages to express the latter. Numerous frameworks have been designed to model IS and EA of various sectors, e.g., Cimosa [13], ArchiMate ${ }^{\circledR}$ [2], HL7 [41], DODAF [42], BSE [43], etc.

Table III provides a review of some metamodels and languages to depict: the context targeted, the IS under scope, and some examples of objects addressed.

TABLE III. OBJECT CONCERNED BY THE VALUE

\begin{tabular}{|c|c|c|c|}
\hline \multirow{2}{*}{$\begin{array}{l}\text { Reference/ } \\
\text { Language }\end{array}$} & \multicolumn{3}{|c|}{ Object concerned } \\
\hline & $\begin{array}{l}\text { Context - } \\
\text { Sector }\end{array}$ & $\begin{array}{c}\text { Information } \\
\text { system }\end{array}$ & Example of objects \\
\hline $\begin{array}{c}\text { CIMOSA } \\
{[13]}\end{array}$ & $\begin{array}{l}\text { Production } \\
\text { Industry }\end{array}$ & $\begin{array}{c}\text { Industrial } \\
\text { information } \\
\text { system }\end{array}$ & $\begin{array}{l}\text { Business process, } \\
\text { flow, step, function, } \\
\text { information, resource } \\
\text { and organization } \\
\text { aspects, business } \\
\text { user, control, } \\
\text { capability... }\end{array}$ \\
\hline $\begin{array}{c}\text { ArchiMate }^{\circledR} \\
{[2]}\end{array}$ & Enterprise & $\begin{array}{c}\text { Enterprise } \\
\text { information } \\
\text { system }\end{array}$ & $\begin{array}{l}\text { Service, Actor, role, } \\
\text { process, function, } \\
\text { contract, software, } \\
\text { data, capability, role, } \\
\text { device, node... }\end{array}$ \\
\hline HL7 [41] & Healthcare & $\begin{array}{c}\text { Clinical } \\
\text { document } \\
\text { architecture }\end{array}$ & $\begin{array}{c}\text { Organization, } \\
\text { Clinical document, } \\
\text { Author, Legal } \\
\text { Authenticator, } \\
\text { Person, product, } \\
\text { consumable... }\end{array}$ \\
\hline Demo [3] & Enterprise & $\begin{array}{l}\text { Business } \\
\text { Process, } \\
\text { Information } \\
\text { Systems }\end{array}$ & $\begin{array}{l}\text { Models (Interaction, } \\
\text { Business Process, } \\
\text { Action, Interstriction, } \\
\text { Fact), Actor, } \\
\text { Action... }\end{array}$ \\
\hline $\begin{array}{c}\text { DODAF } \\
{[42]}\end{array}$ & Military & $\begin{array}{c}\text { DoDAF } \\
\text { Meta-Model } \\
\text { (DM2) }\end{array}$ & $\begin{array}{c}\text { Guidance, activity, } \\
\text { capability, resource, } \\
\text { performer, location, } \\
\text { information, project } \\
\text { materiel, system, } \\
\text { service, } \\
\text { organization... }\end{array}$ \\
\hline
\end{tabular}

\begin{tabular}{|c|c|c|c|}
\hline ARIS [13] & Enterprise & $\begin{array}{c}\text { Business } \\
\text { process } \\
\text { management }\end{array}$ & $\begin{array}{c}\text { Data, Function, } \\
\text { Organization, } \\
\text { Material, IT } \\
\text { resources, or } \\
\text { Machine resources... }\end{array}$ \\
\hline BSE [43] & Enterprise & $\begin{array}{c}\text { Business } \\
\text { Service } \\
\text { Ecosystem }\end{array}$ & $\begin{array}{c}\text { Service, Capability, } \\
\text { Resource, Process, } \\
\text { Actor... }\end{array}$ \\
\hline$\ldots$ & & & \\
\hline
\end{tabular}

As a summary and according to our analysis, the concepts which define the context and the object concerned by the value are:

- Information system. The information system that encompasses the objects concerned by the value.

- Context. The context represents the surrounding of the IS (e.g., the sector and the sector purpose of the business entity that is concerned by the IS, the rules and regulations related to the sector or the IS, etc.)

- Language. The language represents the vocabulary used to express the information system of a specific context.

Based on the above definitions, the context and the object concerned by the value have been modeled in Fig. 4 .

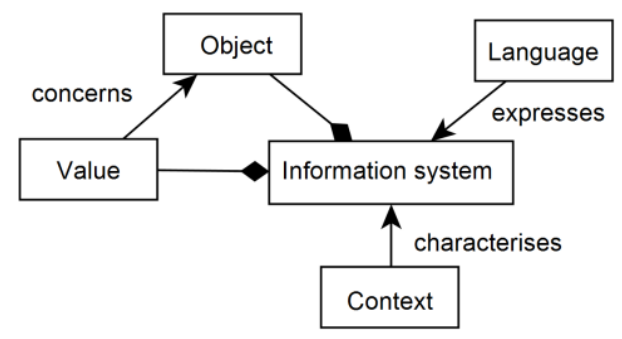

Fig. 4. Object concerned by the value

\section{TOWARD A CONCRETE VCC LANGUAGE CONSIDERING THE 3 VALUE DIMENSIONS}

As reviewed in the state of the art, value co-creation has always been analyzed at a high abstraction level and mainly with the objective to explain the co-creation of the value without describing what value it precisely stands for.

In traditional dyadic co-creation models, one firm collaborates with a customer in order to understand how value could be generated for this customer in exchange of money. In return, the latter has some obligations like sharing information with the firm and co-creating new value propositions which, afterwards, can be embedded in services sold by the firm. The existing co-creation processes focus on the nature of the value for the customer but does not consider the value generated back for the firm. Current approaches roughly consider that the firm benefits from the co-creation process by being afterward paid for the service delivered, and hence, by getting money from the customer.

This section aims to demonstrate that the three dimensions explained in Section III influence the established VCC models (e.g., [14], [16], [17]). Indeed, considering combinations of some dimensions from the tuple (value nature, method of value creation, and object concerned by the value) allows 
extending and enriching the notion of VCC and value-inexchange. Acknowledging the three value dimensions allows better understanding the VCC, and more especially the VCC processes between companies: (A) by considering the context of the object of value for stakeholders, (B) by considering different nature of the value for each party involved and, $(\mathrm{C})$ by considering different VCC methods at each party's side.

Having observed that value may be described following three dimensions, we also acknowledge that value may be cocreated depending on the level of the dimension at which enterprises collaborate. I.e., the collaboration may happen following three basic schemas: (1) at the methodological level, because the enterprises engaged in co-creation share some methodological elements, (2) at the physical level, because companies evolve in the same environment and share common objects concerned by the value, or (3) at the nature of the value level, because companies create the same type of value nature. At a modeling point of view, this means that depending on the type of collaboration, one or more concepts of the three value dimension models (Fig. 2, 3 and 4) are common to the companies.

Table IV illustrates possible combinations when 2 actors are engaged in VCC. When one actor creates value for its own and does not collaborate with another, schema 1 applies. These schemas are represented by, and include, the nature of the value concerned (Circle), the method of value creation (Triangle), and the business object impacted by the value (Rectangle). The company is represented in a dash-line circle, e.g., Company $A$ and $B$ on Table IV.

\section{A. Co-creation of different objects of different values}

This co-creation happens at the methodological level and is represented by the schema $2 \mathrm{a}$ in Table IV. On this schema, the concept of method (in blue) is shared by the companies but the nature of the value and the object of value created are different. In this co-creation case, VCC activities achieved by two companies may generate different types of value nature and that, concerning different objects evolving in different contexts. As a result, the co-creation described in this first schemas happens because enterprises share and achieve activities together that contribute to value creation.

For instance, in the financial sector, to monitor the level of privacy, a bank performs regular privacy impact assessments (PIA). In parallel, to monitor the quality of the service delivered, the bank's data-center performs gap analysis processes (GAP) that allow estimating the level of compliance between the real level of quality and the expected one. Both methods, the PIA and the GAP, are different and have for objective to generate two values of different nature in two different contexts. However, it may happen that in some cases, some steps of both methods overlap and, as a result, may be conducted jointly by the bank and its data center, and be mutually enriched or optimized. For instance, regarding the case here above, to perform the PIA and the GAP, the data center and the bank have to audit the efficiency of the secure lease line.

TABLE IV. SYNOPTIC VIEW ON VALUE CO-CREATION SCHEMAS BASED ON THE 3 VALUE DIMENSIONS

\begin{tabular}{|l|l|c|c|}
\hline $\begin{array}{c}\text { Number } \\
\text { of Actors }\end{array}$ & Id & Description \\
\hline & 1 & Value Creation \\
\hline Co-creation of different \\
objects of different \\
values
\end{tabular}

This audit may be co-realized through a collaboration of experts from both entities who decide to co-achieve some tasks, to synchronize during dedicated meetings, and so forth. Another option is that some parts of this audit may be coacquired from a sub-contracted third party.

\section{B. Separated creation of different objects which create the same value}

This co-creation concerns the nature of the same value and is represented by schema $2 b$ presented in Table IV. In this schema, the concept of nature of the value (in red) is shared by the companies but the object of value created and the value creation method are different.

VCC activities from two companies may be achieved by using different methods and may concern different types of objects from different contexts, however, these different activities concern the co-creation of value of the same nature. This could be the case, for instance, in the healthcare sector, where the accounting department of a hospital sends invoices to the patients, with the name of the doctor visited but using a codification for medical treatments. Having received the invoice, the patient forwards it, to the insurance company for refund. The latter uses the same codification to calculate the amount to be paid back and transfers the cash to the patient's bank account without any reference to the doctor having provided the treatment. In this simple case, the privacy of the patient (nature of the value) is co-created by the hospital using 
a codification on the invoice, and by the insurance company using a disclosure of the doctor's reference.

The context represents the internal and external environment of the company. The external context represents the laws and the rules that constraint the organization, the company's business partnerships, etc. The internal context represents the internal organization of the company, including its structure, hierarchy, information system etc. As illustrated in the case above, the same VCC process happens in two different contexts and it is necessary, to be the most relevant as possible, that each of the parties is aware of the context that characterizes the IS of the other party. For instance, it is important that the assurance company knows about the codification rules of the treatments. Additionally, regarding the external context, in order to foster the VCC, it is also relevant that each of parties knows about the other party's context. For instance, the assurance company should know about the legal requirement of the hospital to identify the right type of value (e.g., the privacy of the patients) that the hospital expects and vice-versa.

\section{Separated creation of a shared object which creates different values}

This co-creation concerns a unique object that creates value of different natures in different contexts. It concerns schema $2 \mathrm{c}$ presented in Table IV.

Two or more companies may require to collaborate to cocreate value but this value may be of different nature for each of them. Classically, one service provider co-creates value with a customer in exchange of money. For the customer, the nature of the value is a function of the service delivered by the service provider (it may be for instance the delivery of a report, the deployment of a security tool, etc.) and for the service provider, the value is of a pecuniary value (e.g., the customer pays for the service).

Another example is the case of a retailer who receives an order from a supermarket through a just in time integrated process. In this case, the supermarket collaborates with the retailer to improve the rapidity of the process, and in return, the retailer collaborates with the supermarket to improve the quality of the service offered. In this case, two types of nature of value are generated through the same value co-creation activity: rapidity of the process for the supermarkets and quality of the service for the retailer.

\section{Integrated VCC}

Understanding and considering the three dimensions of the value allows improving and optimizing the definition of the value creation at company level. This is also the case when VCC occurs between two companies, as illustrated through the three different value schemas presented in previous section.

In practice, it is worth to note that co-creation is not limited to the basic schemas presented in Table IV. Two complementary co-creation variants exist. The first one happens when more than two companies are involved in one dimension of the VCC. E.g., in the case of the healthcare sector, a third company could also act to protect the privacy of the patient like for instance an independent audit company or second healthcare practitioner who accesses the information from the doctor and writes a second report while also guaranteeing the patient's privacy. This case should be represented according to the schema on the left side of Fig. 5 that expresses that Companies $A, B$ and $C$ create value of a privacy nature (red circle). A second possible co-creation could happen when co-creation of value between two companies concerns more than one dimension, as represented on the right side of Fig. 5.
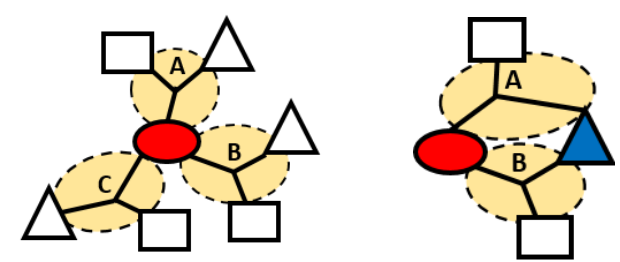

Fig. 5. Co-creation variants

A stronger integration of both companies is observable in this schema due to the fact that Companies $A$ and $B$ co-create value of the same nature and use some shared methodological elements. This is, for instance the case, in the financial sector, where co-creation happens when both the bank and its data center achieve activities in common to generate the same value nature. E.g., the bank achieves a PIA to generate privacy value, the data center achieves a GAP of its business processes in comparison with the GDPR (General Data Protection Regulation - [44]), and both collaborate to achieve some identical tasks of the PIA and of the GAP.

Finally, a complete system of VCC activity may also be represented based on different existing schemas (Fig. 6).

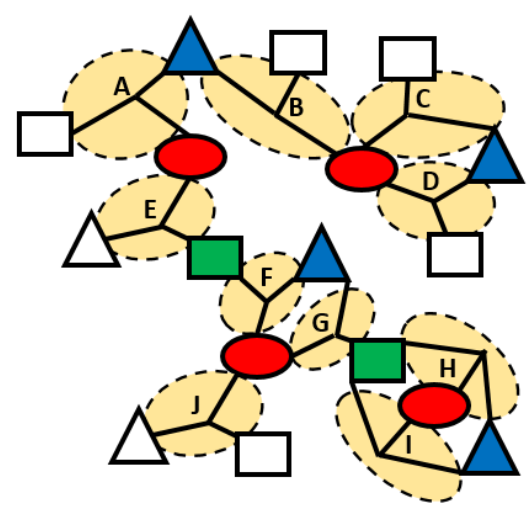

Fig. 6. Integrated VCC view

Optimizing VCC is now feasible because, based on the models defined in Section III, it is possible to identify in the three dimensions the elements that are common to the different values co-created at each side of the traditional dyadic VCC. E.g., it is possible that step $\mathrm{x}$ of the method for VCC in the first company (e.g., method 1) is the same as step $\mathrm{Y}$ of another method (e.g., method 2) for VCC in the second 
company. E.g., the analysis of the risk and benefit of the VCC process can be achieved jointly by both companies.

It is also possible that an element $\mathrm{x}$ of the context in the first company (e.g., context 1) is the same as element y of another context in the second company. E.g., two companies from two different sectors co-create value in order to face a unique regulation that applies in both contexts.

Finally, while two companies co-create values that have two different natures, it is possible that some characteristics are common and may be handled jointly. E.g., company 1 and 2 work and co-create value together, but for company 1 the value means more privacy and for company 2 , the value means more security of the information. In both cases, both natures of value have a common characteristic which is to set up the confidentiality (given that confidentiality is a characteristic of privacy and of security).

It is also conceivable to have a more integrated approach like for instance, one step of method 1 contributes to 1 characteristic of nature 2 , one element of context 1 is addressed using one step of method 2, or one element of nature 1 is a requirement of one element of the context $2 \ldots$

\section{TOWARD A CONCRETE VCC LANGUAGE}

As explained in the introduction, two or more companies engaged in VCC must know each other and communicate in order to detect, design, and manage the collaborations where value is/could be co-created. Therefore, these companies need to be supported by a single language in order to share a common understanding of the concepts' semantic and meaning. Unfortunately, designing one unique concrete language to express all the dimensions of the VCC remains utopical for many reasons like, as explained in the introduction, the habits of a company, the different natures of value, the enterprise context in which the objects concerned by the value exist, the different layers of VCC, etc. Accordingly, the three value dimensions introduced in Section III (and based on their corresponding model) can be considered as a valuable intermediary language to support the relationships amongst different languages, from different layers, with different concrete syntaxes, tailored to express different value natures. The language interoperability using the abstract value co-creation language is made possible on the basis of chains of conceptual mappings between language concepts. Depending on the VCC schemas (see Table IV) and both co-creation variants (see Fig. 5), a plethora of chains may potentially be designed. For instance:

- In the case of schema 1 of Table IV, the conceptual mappings chain may be the following: Domain language enterprise $1 \rightarrow$ Value dimension 1 (abstract language) $\rightarrow$ Value dimension 2 (abstract language) $\rightarrow$ Domain language enterprise 2. E.g., an operation manager who wishes to assess the process at risk must communicate with the risk manager. At a language level, the conceptual mapping is the following: Process reference model $\rightarrow$ Object concerned by the value $\rightarrow$ Value creation method $\rightarrow$ Risk domain.
- In the case of schemas $2 \mathrm{a}, \mathrm{b}, \mathrm{c}$, the conceptual mapping chain may be the following: Domain language enterprise $1 \rightarrow$ Unique value dimension (abstract language) $\rightarrow$ Domain language enterprise 2

- In the case of more than two companies involved in one dimension of the VCC, the conceptual mapping chain may be the following: Domain language enterprise $1 \rightarrow$ Unique value dimension (abstract language) $\rightarrow$ Domain language enterprise $2,3 \ldots \mathrm{n}$.

- In the case of value co-creation between two companies concerning more than one dimension, the conceptual mapping chain may be a function of the required integration, and different possibilities arise.

In most cases, more than one value dimension is concerned by the conceptual mapping. The conceptual mapping between more domain languages (from one or more companies) is, as a result, potentially based on the integration of the three value dimensions. This integration, illustrated in Fig. 7, constitutes the core of the conceptual mapping. It is elaborated on the concept of value which concerns the concept of object. Both concepts are existing in the three dimensions of the value and constitute, hence, the appropriate trade-off amongst the latter.

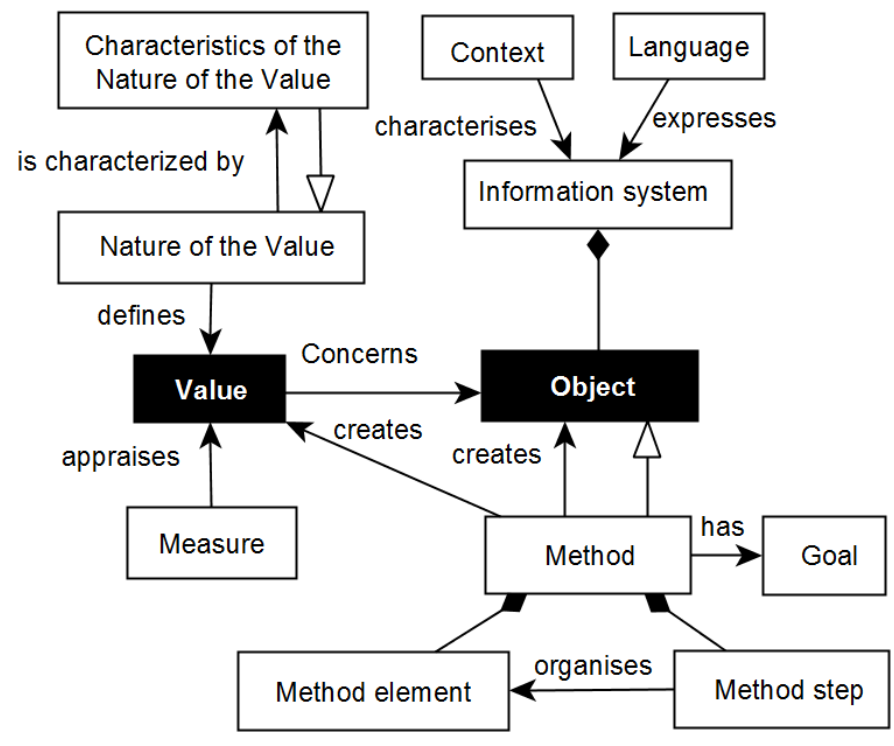

Fig. 7. Integrated three value dimensions

\section{VALIDATION BY APPLYING MOODY GUIDELINES}

The evaluation of the three dimensions-based abstract language to support VCC is performed at the level of cognitive effectiveness, i.e. the effectiveness of the language to convey information to a group of specific persons (e.g., enterprise analysts, experts of the value modeling, managers...).

This assessment of the cognitive effectiveness of the language is based on the work of Moody that establishes the foundation for a science of visual notation design called "The Physics of Notations" [45]. Moody has defined a set of nine principles for designing "cognitive effective visual notations". These principles are based on the theory and empirical evidences about cognitive effectiveness of visual 
representation. They constitute what Moody calls the prescriptive theory for visual notation and they allow shifting from unselfconscious into a subconscious process of visual notation design. Table $\mathrm{V}$ summarized the analysis of the compliance of the VCC abstract language in regard to the nine principles defined by Moody. The table reminds the definition of the principles and how the language is compliant to the latter.

As a conclusion of the evaluation, we observe first that the majority of the principles are respected, second that the principles of complexity management and cognitive fit are irrelevant provided the abstract characteristic of the designed language, and third that the principles of complexity management and dual coding are partially respected. These principles should be improved in future works.

TABLE V. LANGUAGE VALIDATION

\begin{tabular}{|c|c|c|}
\hline Principle & Definition & VCC abstract language \\
\hline $\begin{array}{l}\text { Principle of } \\
\text { semiotic } \\
\text { clarity }\end{array}$ & $\begin{array}{l}\text { There should be a } \\
1: 1 \text { correspondence } \\
\text { between semantic } \\
\text { constructs and } \\
\text { graphical symbols }\end{array}$ & $\begin{array}{l}\text { This principle is respected. Each } \\
\text { semantic dimension of the value, the } \\
\text { company, and the value created in } \\
\text { the company is represented by a } \\
\text { symbol. }\end{array}$ \\
\hline $\begin{array}{l}\text { Principle of } \\
\text { complexity } \\
\text { management }\end{array}$ & $\begin{array}{l}\text { Explicit mechanisms } \\
\text { for dealing with } \\
\text { complexity should } \\
\text { be included, such as } \\
\text { modularization or } \\
\text { hierarchy. }\end{array}$ & $\begin{array}{l}\text { This principle is more relevant for } \\
\text { complex languages. As we propose } \\
\text { an abstract language, we do not have } \\
\text { to deal with the complexity of } \\
\text { concrete instantiations. }\end{array}$ \\
\hline $\begin{array}{l}\text { Principle of } \\
\text { semantic } \\
\text { transparency }\end{array}$ & $\begin{array}{l}\text { Visual } \\
\text { representations } \\
\text { whose appearance } \\
\text { suggests their } \\
\text { meaning should be } \\
\text { used. }\end{array}$ & $\begin{array}{l}\text { This principle is partially respected. } \\
\text { The relations between the } \\
\text { companies that co-create value } \\
\text { clearly appear, however, the value } \\
\text { dimension is not deductible enough. }\end{array}$ \\
\hline $\begin{array}{l}\text { Principle of } \\
\text { cognitive fit }\end{array}$ & $\begin{array}{l}\text { Different visual } \\
\text { dialects should be } \\
\text { used for different } \\
\text { tasks and audiences. }\end{array}$ & $\begin{array}{l}\text { This principle is not relevant } \\
\text { provided that we propose an abstract } \\
\text { language. The principle of cognitive } \\
\text { fit will be meaningful at the } \\
\text { instantiation level, respectively, } \\
\text { when languages from different } \\
\text { audiences are integrated on the basis } \\
\text { of the abstract language. }\end{array}$ \\
\hline $\begin{array}{l}\text { Principle of } \\
\text { cognitive } \\
\text { integration }\end{array}$ & $\begin{array}{l}\text { Explicit mechanisms } \\
\text { to support } \\
\text { integration of } \\
\text { information from } \\
\text { different diagrams } \\
\text { should be included. }\end{array}$ & $\begin{array}{l}\text { The principle of cognitive } \\
\text { integration is the core of the abstract } \\
\text { language which aims at establishing } \\
\text { the bases for languages mappings } \\
\text { and integrations. }\end{array}$ \\
\hline $\begin{array}{l}\text { Principle of } \\
\text { cognitive fit }\end{array}$ & $\begin{array}{l}\text { Different visual } \\
\text { dialects should be } \\
\text { used for different } \\
\text { tasks and audiences. }\end{array}$ & $\begin{array}{l}\text { This principle is not relevant } \\
\text { provided that we propose an abstract } \\
\text { language. The principle of cognitive } \\
\text { fit will be meaningful at the } \\
\text { instantiation level, respectively, } \\
\text { when languages from different } \\
\text { audiences are integrated on the basis } \\
\text { of the abstract language. }\end{array}$ \\
\hline $\begin{array}{l}\text { Principle of } \\
\text { dual coding }\end{array}$ & $\begin{array}{l}\text { Text should be used } \\
\text { to complement } \\
\text { graphics }\end{array}$ & $\begin{array}{l}\text { This principle is partially respected. } \\
\text { Text could support the principle of } \\
\text { semantic transparency for } \\
\text { distinguishing between the value } \\
\text { dimensions. }\end{array}$ \\
\hline
\end{tabular}

\begin{tabular}{|c|l|l|}
\hline $\begin{array}{c}\text { Principle of } \\
\text { graphic } \\
\text { economy }\end{array}$ & $\begin{array}{l}\text { The number of } \\
\text { different graphical } \\
\text { symbols should be } \\
\text { cognitively } \\
\text { manageable }\end{array}$ & This principle is respected. \\
\hline $\begin{array}{c}\text { Principle of } \\
\text { perceptual } \\
\text { discriminabi- } \\
\text { lity }\end{array}$ & $\begin{array}{l}\text { Different symbols } \\
\text { should be clearly } \\
\text { distinguishable from } \\
\text { each other. }\end{array}$ & $\begin{array}{l}\text { This principle is respected. The } \\
\text { shapes are clearly different from } \\
\text { each other. }\end{array}$ \\
\hline
\end{tabular}

\section{CONCLUSION AND FUTURE WORKS}

Two or more companies engaged in a VCC must be supported by a dedicated language. Unfortunately, designing a unique concrete syntax to express all the dimensions of the value creation remains utopical. Therefore, in this paper, we have presented the foundation of the three value dimensions which aims at defining an abstract language to support VCC: the dimensions that constitute the pillars of the language to express the nature of the value (e.g., privacy, money, security, quality...), the object concerned by the value (information, process, business asset...), and the method for value creation (risk management, gap analysis, model-driven, method chunk...).

Based on these dimensions, a set of schemas for value (co)creation has been proposed and illustrated in different sectors. In parallel, two value co-creation variants have been explained, respectively: when more than two companies are involved and when VCC between two companies concerns more than one dimension. Afterwards, the paper has presented some clues on the way conceptual mapping chains may be designed, using the three dimensions-based abstract language in order to support the value (co)creation management amongst enterprises from different sectors, considering different value nature and using different value creation methods. Finally, the designed abstract language has been evaluated in regard with Moody's nine principles for designing "cognitive effective visual notations".

Concerning future works, as argued by the DSR theory [29], [30], additional iterations are continuously required to improve and validate the designed abstract language, at the model level and at the visual notation level. In that regard, we intend in the next months, to exploit the language to support the co-creation of the value in the context of business exchange between road operators. Secondly, the abstract language needs to be enriched with complementary symbols in order to sustain the definition of chains of conceptual mapping related to some classical and frequent value dimensions, e.g., security, privacy, but also specific sectors, e.g., healthcare or public administrations.

\section{REFERENCES}

[1] J. Gordijn, H. Akkermans, and H. Van Vliet, "Designing and evaluating e-business models," IEEE intelligent Systems, vol. 16, no. 4, pp. 11-17, Jul. 2001. DOI:10.1109/5254.941353

[2] A. Josey, M. Lankhorst, I. Band, H. Jonkers, and D. Quartel, "An Introduction to the ArchiMate ${ }^{\circledR} 3.0$ Specification," White Paper from The Open Group, Jun. 2016. 
[3] J. L. G. Dietz, "Understanding and modelling business processes with DEMO," Int. Conf. on Conceptual Modeling, 1999, pp. 188-202. DOI:10.1007/3-540-47866-3_13

[4] OMG, "Value Delivery Metamodel Vers. 1.0," OMG Document, No: formal/2015-10-05.

[5] R. Matulevicius, N. Mayer, and P. Heymans, "Alignment of misuse cases with security risk management," in $3^{\text {rd }}$ Int. Conf. on Availability, Reliability and Security IEEE, 2008. pp. 1397-1404. DOI:10.1109/ARES.2008.88

[6] C. Calero, J. Ruiz, and M. Piattini, "Classifying web metrics using the web quality model," Online Inf. Review, vol. 29, no. 3, pp. 227-248, Jun. 2005. DOI:10.1108/14684520510607560

[7] C. Feltus, E. Grandry, T. Kupper, and J. N. Colin, "Model-Driven Approach for Privacy Management in Business Ecosystem," in $5^{\text {th }}$ Int. Conf. on Model-Driven Eng. and Software Development, 2017. DOI: $10.5220 / 0006142203920400$

[8] M. Langheinrich, "Privacy by design-principles of privacy-aware ubiquitous systems," in Int. Conf. on Ubiquitous Computing, 2001, pp. 273-291. DOI:10.1007/3-540-45427-6_23

[9] x, "Privacy by Design: Effective Privacy Management in the Victorian public sector," Release date: Oct. 2014.

[10] J. Ralyté, "Towards situational methods for information systems development: engineering reusable method chunks, " in Procs. of $13^{\text {th }}$ Int. Conf. on Inf. Sys.Development. Advances in Theory, Practice and Education. 2004.

[11] F. Bénaben, J. Touzi, V. Rajsiri, S. Truptil, J. P. Lorré, and H. Pingaud, "Mediation information system design in a collaborative SOA context through a MDD approach," in Procs. of MDISIS, 2008, pp. 89-103

[12] A. W. Scheer, and M. Nüttgens, "ARIS architecture and reference models for business process management," Business Process Management, 2000, pp. 376-389. DOI:10.1007/3-540-45594-9_24

[13] G. Berio and F. Vernadat, "Enterprise modelling with CIMOSA: functional and organizational aspects," Production planning \& control, $\begin{array}{lllll}\text { vol. } 12, \quad \text { no. } 2, \quad \text { pp. } 128-136, & \text { Jan } 2001 .\end{array}$ DOI: $10.1080 / 09537280150501239$

[14] C. Grönroos, "Service logic revisited: who creates value? And who cocreates?," European business review, vol. 20, no. 4, pp. 298-314, 2008. DOI:10.1108/09555340810886585

[15] V. A. Zeithaml, "Consumer perceptions of price, quality, and value: a means-end model and synthesis of evidence," The journal of marketing, pp. 2-22, Jul. 1988. DOI:10.2307/1251446

[16] S. L. Vargo and R. F. Lusch, "Service-dominant logic: continuing the evolution," Journal of the Academy of marketing Science, vol. 36, no. 1, pp. 1-10, Mar. 2008. DOI:10.1007/s11747-007-0069-6

[17] S .L. Vargo and R. F. Lusch, "Evolving to a new dominant logic for marketing," Journal of marketing, vol. 68, no. 1, pp. 1-17, Jan. 2004. DOI: 10.1509/jmkg.68.1.1.24036

[18] A. F. Payne, K. Storbacka, and P. Frow, "Managing the co-creation of value," Journal of the academy of marketing science, vol. 36, no. 1, pp. 83-96, Mar 2008. DOI:10.1007/s11747-007-0070-0

[19] H. Hastings and J. Saperstein, "A practice-driven service framework for value creation," in $15^{\text {th }}$ Conf. on IEEE Business Informatics, 2013, pp. 145-152. DOI:10.1109/CBI.2013.29

[20] K. Storbacka, R. J. Brodie, T. Böhmann, P. P. Maglio, and S. Nenonen, "Actor engagement as a microfoundation for value co-creation," Journal of Business Research, vol. 69, no. 8, pp. 3008-3017, Aug. 2016. DOI:10.1016/j.jbusres.2016.02.034.

[21] P. Frow, S. Nenonen, A. F. Payne, and K. Storbacka, "Managing Co-creation Design: A Strategic Approach to Innovation," British Journal of Management, vol. 26, no. 3, pp. 463-483, Jul. 2015. DOI: 10.1111/1467-8551.12087

[22] E. K. Chew, "iSIM: An integrated design method for commercializing service innovation," Information Systems Frontiers, vol. 18, no. 3, pp. 457-478, Jun. 2016. DOI: 10.1007/s10796-015-9605-y

[23] J. Gordijn, H. Akkermans, and H. Van Vliet, "Business modelling is not process modelling," In Int. Conf. on Conceptual Modeling, 2000, pp. 4051. DOI:10.1007/3-540-45394-6_5
[24] H. Weigand, "Value encounters-modeling and analyzing co-creation of value," in Conf. on e-Business, e-Services and e-Society, 2009, pp. 5164. DOI:10.1007/978-3-642-04280-5_5

[25] I. S. Razo-Zapata, E. K. Chew, and E. Proper, "Visual Modeling for Value (Co-) Creation," in $10^{\text {th }}$ Int. Workshop on Value Modeling and Business Ontologies, 2016.

[26] H. Alves, C. Fernandes, and M. Raposo, "Value co-creation: Concept and contexts of application and study," Journal of Business Research, vol. 69, no. 5, pp 1626-1633, May 2016. DOI:10.1016/j.jbusres.2015.10.029

[27] K. R. Ranjan and S. Read, "Value co-creation: concept and measurement," Journal of the Academy of Marketing Science, vol. 44, no. 3, pp. 290-315, May 2016. DOI: 10.1007/s11747-014-0397-2

[28] M. Galvagno and D. Dalli, "Theory of value co-creation: a systematic literature review," Managing Service Quality, vol. 24, no. 6, pp. 643683, Nov. 2014. DOI:10.1108/MSQ-09-2013-0187

[29] R. Hevner, S. T. March, and J. Park, "Design science in information systems research," MIS quarterly, vol. 28, no. 1, 2004. DOI: 10.1007/978-1-4419-5653-8_2

[30] K. Peffers, T. Tuunanen, M. A. Rothenberger, and S. Chatterjee, "A design science research methodology for information systems research," Journal of management information systems, vol. 24, no. 3, pp. 45-77, Dec. 2008. DOI: 10.2753/MIS0742-1222240302

[31] A. Smith, "The Wealth of Nations (1776)," New York: The Modern Library. 2000.

[32] J. Nyman, "What is the value of security? Contextualising the negative/positive debate," Review of Int. Studies, 2016, pp. 1-19. DOI: 10.1017/S0260210516000140

[33] O. Korkman, "Customer value formation in practice: a practicetheoretical approach," Svenska handelshögskolan, 2006.

[34] M. Theoharidou, A. Mylonas, and D. Gritzalis, "A risk assessment method for smartphones," in IFIP Int. Inf. Sec. Conf., 2012. DOI:10.1007/978-3-642-30436-1_36

[35] C. Feltus, E. Dubois, and M. Petit, "Alignment of ReMMo with RBAC to manage access rights in the frame of enterprise architecture," in $9^{\text {th }}$ Int. Conf. on Res. Challenges in Inf. Science IEEE, 2015. pp. 262-273. DOI:10.1109/RCIS.2015.7128887

[36] R. M. Foorthuis, F. Hofman, S. Brinkkemper, and R. Bos, “Assessing business and IT projects on compliance with enterprise architecture," in Procs. of GRCIS, 2009. DOI:10.4018/jdm.2012040103

[37] A. Dix, "Human-computer interaction: A stable discipline, a nascent science, and the growth of the long tail," Interact. Comput., vol. 22, no. 1, Jan. 2010. 13-27. DOI:10.1016/j.intcom.2009.11.00

[38] H. Becker, "Social impact assessment: method and experience in Europe, North America and the developing world," Routledge, Jan. 2014 DOI:10.1002/1099-162X(200010)20:4<353::AID-PAD75>3.0.CO;2-9

[39] I. Manuj and J. T. Mentzer, "Global supply chain risk management," Journal of business logistics, vol. 29, no. 1, pp. 133-155, Mar. 2008. DOI:10.1108/09600030810866986

[40] M. Daneva, "Applying real options thinking to information security in networked organizations," No. TR-CTI. Centre for Telematics and Information Technology, University of Twente, 2006.

[41] R. H. Dolin, L. Alschuler, S. Boyer, C. Beebe, F. M. Behlen, P. V. Biron, and A. Shabo, "HL7 clinical document architecture, release 2," Journal of the American Medical Informatics Association, vol. 13, no. 1, pp. 30-39, Jan. 2006. DOI:10.1197/jamia.M1888

[42] DoDAF framework, http://dodcio.defense.gov/Library/DoDArchitecture-Framework/dodaf20_logical/

[43] C. Feltus, F. X. Fontaine, and E. Grandry, "Towards Systemic Risk Management in the Frame of Business Service Ecosystem," in Int. Conf. on Advanced Inf. Sys. Eng., 2015. DOI:10.1007/978-3-319-19243-7_3

[44] Council of European Union, "General Data Protection Regulation," 269/2014. http://ec.eu ropa.eu/justice/

[45] D. L. Moody, "The 'physics' of notations: a scientific approach to designing visual notations in software engineering," in ACM/IEEE $32^{\text {nd }}$ Int. Conf. on Software Eng., 2010, vol. 2, pp. 485-486. DOI: $10.1145 / 1810295.1810442$ 